ARTICLE

\title{
Evaluation of Solute-Atom Clusters Segregated in $\alpha-\mathrm{Fe}$
}

\author{
Chikashi SUZUKI*, Tomohito TSURU and Yoshiyuki KAJI \\ Nuclear Science and Engineering Directorate, Japan Atomic Energy Agency, \\ 2-4 Shirakata Shirane, Tokai-mura, Naka-gun, Ibaraki-ken, 319-1195, Japan
}

\begin{abstract}
We examined the interaction between impurities in $\alpha-\mathrm{Fe}$ such as $\mathrm{Cu}, \mathrm{Si}$, and $\mathrm{Ni}$, using the density functional theory (DFT) calculation. This examination indicated that the bond of $\mathrm{Cu}-\mathrm{Si}$ was more stable than that of $\mathrm{Si}-\mathrm{Si}$, and that the interaction parameters of $\mathrm{Cu}-\mathrm{Si}$ and $\mathrm{Si}-\mathrm{Ni}$ were lower than that of $\mathrm{Si}-\mathrm{Si}$. This indicated that $\mathrm{Cu}$ and $\mathrm{Ni}$ impurities encouraged segregation of solute-atom clusters containing $\mathrm{Si}$ atoms but that the interaction of $\mathrm{Cu}-\mathrm{Ni}$ was small. In addition, we evaluated the effect of the coexistence of impurities in the view point of the electronic structure. The electronic structure showed that the coexistence of $\mathrm{Cu}$ and $\mathrm{Si}$ lowered energy of $\mathrm{Cu}$ and adjacent $\mathrm{Fe}$ component. This suggested that the coexistence of $\mathrm{Cu}$ and $\mathrm{Si}$ stabilized $\mathrm{Cu}$ and adjacent $\mathrm{Fe}$ component.
\end{abstract}

KEYWORDS: segregation, impurity, solute-atom cluster, interaction parameter, electronic structure

\section{Introduction}

It has been important to obtain the understanding of the controlling mechanism that causes reactor pressure vessel (RPV) embrittlement. This involves detailed characterization of the irradiation-induced microsructural changes and their dependence on material and irradiation parameter. Especially it is noted that the segregation and clustering are observed as the form of solute-atom clusters in low alloy steels of RPV irradiated for many years. These clusters are thought to be the causes of irradiation-induced embrittlement. ${ }^{1-5)}$ Among impurities of low alloy steels of RPV, $\mathrm{Cu}$ has been thought to be dominant constituent for solute-atom clusters. In recent years, the three-dimensional atom probe (3DAP) observation of the surveillance test specimens of irradiated low alloy steels of RPV indicates that clusters segregated in these specimens contain other elements than $\mathrm{Cu}$ such as $\mathrm{Ni}, \mathrm{Mn}, \mathrm{Si}$, and $\mathrm{P}^{6)}$ Besides, solute-atom clusters are observed in the specimens of low- $\mathrm{Cu}$ alloy steels of RPV and $\mathrm{Cu}$ is not dominant constituent in these clusters. ${ }^{7)}$ Furthermore, the 3DAP observation of irradiated ferrite model alloys shows that the component fractions of $\mathrm{Ni}, \mathrm{Mn}$, and $\mathrm{Si}$ in solute-atom clusters are similar and much larger than those of the ferrite model alloys for various values of $\mathrm{Cu}$ concentration and cluster size. ${ }^{8,9)}$

Tsuru et al. ${ }^{10)}$ investigated the impurity segregation in $\alpha-F e$ using the density functional theory (DFT) calculation in detail, and predicted this segregation for various impurity elements. However, a few elements are observed as the form of solute-atom clusters though it is predicted that the cluster creation is unstable. Besides, Ohmura et al. ${ }^{11)}$ evaluated the interaction between impurity atoms and vacancies in detail.

In this study, in order to examine the behaviors of some elements such as $\mathrm{Cu}, \mathrm{Si}$, and $\mathrm{Ni}$ of the high concentration for

*Corresponding author, E-mail: suzuki.chikashi@jaea.go.jp

(C) 2011 Atomic Energy Society of Japan, All Rights Reserved. the solute-atom clusters as a fundamental investigation, we perform the DFT calculation for these clusters, because the short-range interaction between first or second neighboring atoms in solute-atom clusters of nano-size and the interaction between different elements are likely to be important. Moreover, we evaluate these interactions from the view point of the electronic structure.

\section{Calculation}

In this study, we used the DFT calculation code PHASE ver. $7.01^{12)}$ with a periodic boundary condition. Exchangecorrelation energy was described using the Perdew-BurkeErnzerhof (PBE) gradient-corrected exchange-correlation function within the generalized gradient approximation (GGA), ${ }^{13)}$ with spin polarization. The core electrons of all atoms were treated via ultra-soft pseudo potentials ${ }^{14,15)}$ with a cut-off of $500 \mathrm{eV}$. The geometry optimization was performed using a $7 \times 7 \times 7$ Monkhorst-Pack k-point mesh. A Fermi smearing of $0.2 \mathrm{eV}$ was utilized and the corrected energy was extrapolated to zero Kelvin.

The average composition values of $\mathrm{Si}$ and $\mathrm{Ni}$ in the solute-atom cluster in irradiated ferrite model alloys show high-concentration of 3-20\%, though those before the irradiation are below $2.0 \% .{ }^{8,9)}$ The average composition value of $\mathrm{Cu}$ in the solute-atom cluster is much larger than those before the irradiation. ${ }^{8,9)}$ For simplicity for various composition values, crystal structure of $\alpha-\mathrm{Fe}$ is bcc and the calculations were performed on $2 \times 2 \times 2$ supercells (16 atoms), which are $\mathrm{Fe}_{16}, \mathrm{CuFe}_{15}, \mathrm{SiFe}_{15}$, and $\mathrm{NiFe}_{15}$. The short-range interactions between first or second neighboring atoms are likely to be significant due to the nano-size of the solute-atom cluster in addition to the high concentration of impurities, so that the models of $\mathrm{Cu}_{2} \mathrm{Fe}_{14} \mathrm{Si}_{2} \mathrm{Fe}_{14}, \mathrm{Ni}_{2} \mathrm{Fe}_{14}, \mathrm{CuSiFe}_{14}, \mathrm{CuNiFe}{ }_{14}$, and $\mathrm{SiNiFe}_{14}$ are calculated for two kinds considering the first and second neighboring bonds between impurities $(\mathrm{Cu}$, 
$\mathrm{Si}$, and $\mathrm{Ni}$. The calculated lattice constant of supercell is $5.69 \AA$, which is comparable to the value in the literature. ${ }^{16)}$ Geometry optimizations were stopped when all the forces were smaller than $0.02 \mathrm{eV} / \AA$. No symmetry constraints are imposed. For simplicity, the effect of stress relaxation is not taken in account.

\section{Result and Discussion}

\section{Interaction between Impurities}

We examine the interaction between impurities such as $\mathrm{Cu}$, $\mathrm{Ni}$, and $\mathrm{Si}$ atoms for the fundamental investigation. These elements are observed in the irradiated $\alpha$-Fe metal. The first neighboring interaction between impurities is defined as.

$E_{\text {int }}^{1 \text { st }}\left(\mathrm{I}_{\mathrm{a}}-\mathrm{I}_{\mathrm{b}}\right)$

$$
=E^{1 \mathrm{st}}\left(\mathrm{I}_{\mathrm{a}} \mathrm{I}_{\mathrm{b}} \mathrm{Fe}_{14}\right)+E\left(\mathrm{Fe}_{16}\right)-E\left(\mathrm{I}_{\mathrm{a}} \mathrm{Fe}_{15}\right)-E\left(\mathrm{I}_{\mathrm{b}} \mathrm{Fe}_{15}\right)
$$

Here, $\mathrm{I}_{\mathrm{a}}$ and $\mathrm{I}_{\mathrm{b}}$ are expressed as impurity elements, and $E^{1 \mathrm{st}}$ $\left(\mathrm{I}_{\mathrm{a}} \mathrm{I}_{\mathrm{b}} \mathrm{Fe}_{14}\right), E\left(\mathrm{Fe}_{16}\right), E\left(\mathrm{I}_{\mathrm{a}} \mathrm{Fe}_{15}\right)$, and $E\left(\mathrm{I}_{\mathrm{b}} \mathrm{Fe}_{15}\right)$ are energy values of $\mathrm{I}_{\mathrm{a}} \mathrm{I}_{b} \mathrm{Fe}_{14}$ (first neighboring bond of $\mathrm{I}_{\mathrm{a}}-\mathrm{I}_{\mathrm{b}}$ ), $\mathrm{Fe}_{16}, \mathrm{I}_{\mathrm{a}} \mathrm{Fe}_{15}$, and $\mathrm{I}_{\mathrm{b}} \mathrm{Fe}_{15}$ in the unit cell. The second neighboring interaction between impurities is also defined as,

$$
\begin{aligned}
& E_{\text {int }}{ }^{2 \text { nd }}\left(\mathrm{I}_{\mathrm{a}}-\mathrm{I}_{\mathrm{b}}\right) \\
& \quad=E^{2 n d}\left(\mathrm{I}_{\mathrm{a}} \mathrm{I}_{\mathrm{b}} \mathrm{Fe}_{14}\right)+E\left(\mathrm{Fe}_{16}\right)-E\left(\mathrm{I}_{\mathrm{a}} \mathrm{Fe}_{15}\right)-E\left(\mathrm{I}_{\mathrm{b}} \mathrm{Fe}_{15}\right)
\end{aligned}
$$

We consider this interaction between first neighboring atoms and that between second neighboring atoms, because that between second neighboring atoms cannot be ignored in bcc metals. The interactions between impurities are shown in Table 1.

Table 1 shows that the stability of the interaction between impurities is $\mathrm{Cu}-\mathrm{Cu}>\mathrm{Ni}-\mathrm{Ni}>\mathrm{Si}-\mathrm{Si}$. This tendency is coincident with the calculation ${ }^{10)}$ with larger unit cell of 54 atoms. The first neighboring interaction of $\mathrm{Cu}-\mathrm{Cu}$ and $\mathrm{Ni}-\mathrm{Ni}$ is more strong than second neighboring one in this calculation, because the absolute values of the first neighboring interaction is larger than those of the second neighboring. Compared with $\mathrm{Cu}-\mathrm{Cu}$ and $\mathrm{Ni}-\mathrm{Ni}$ bond, the second neighboring interaction is important for $\mathrm{Si}-\mathrm{Si}$ bond, because the absolute value of the second neighboring interaction is comparable to that of the first neighboring.

Table 1 Interaction between impurities in $\alpha-\mathrm{Fe}$

\begin{tabular}{ccc}
\hline Unit cell & $\begin{array}{c}\text { Impurity } \\
\text { co-ordination }\end{array}$ & $\begin{array}{c}\text { Interaction } \\
(\mathrm{eV})\end{array}$ \\
\hline $\mathrm{Cu}_{2} \mathrm{Fe}_{14}$ & First neighboring & -0.19 \\
$\mathrm{Cu}_{2} \mathrm{Fe}_{14}$ & Second neighboring & -0.11 \\
$\mathrm{Si}_{2} \mathrm{Fe}_{14}$ & First neighboring & 0.41 \\
$\mathrm{Si}_{2} \mathrm{Fe}_{14}$ & Second neighboring & 0.47 \\
$\mathrm{Ni}_{2} \mathrm{Fe}_{14}$ & First neighboring & 0.21 \\
$\mathrm{Ni}_{2} \mathrm{Fe}_{14}$ & Second neighboring & 0.11 \\
\hline $\mathrm{CuSiFe}_{14}$ & First neighboring & -0.04 \\
$\mathrm{CuSiFe}_{14}$ & Second neighboring & 0.06 \\
$\mathrm{CuNiFe}$ & First neighboring & 0.01 \\
$\mathrm{CuNiFe}$ & Second neighboring & 0.02 \\
$\mathrm{SiNiFe}_{14}$ & First neighboring & 0.12 \\
$\mathrm{SiNiFe}$ & Second neighboring & 0.35 \\
\hline
\end{tabular}

We examine the interaction between different impurities. This examination shows that the bond between $\mathrm{Cu}$ and $\mathrm{Si}$ is more stable than that between Si atoms. This interaction indicates that $\mathrm{Cu}$ impurity encourages segregation of soluteatom clusters containing $\mathrm{Si}$. On the other hand, the first neighboring bond of $\mathrm{Si}-\mathrm{Ni}$ is more stable than those of $\mathrm{Ni}-\mathrm{Ni}$ and of Si-Si.

This stability of the bonds of $\mathrm{Cu}-\mathrm{Si}$ reflects the observation of the segregation of the solute-atom cluster containing both $\mathrm{Cu}$ and $\mathrm{Si}^{6,8,9)}$ though the $\mathrm{Si}$ cluster is likely to be unstable in the analysis considering the bonds of $\mathrm{Si}-\mathrm{Si}$ and $\mathrm{Si}-\mathrm{Fe}$ causing the creation of Si clusters in $\alpha-\mathrm{Fe}^{10)}$

In these calculations, there is one first neighboring bond between impurities and there are two second ones. In the regular solution approximation, the first neighboring interaction between impurities is expressed as

$$
\begin{aligned}
E_{\text {int }}^{1 s t}\left(\mathrm{I}_{\mathrm{a}}-\mathrm{I}_{\mathrm{b}}\right)=e_{\mathrm{I}_{\mathrm{a}}-\mathrm{I}_{\mathrm{b}}}^{1 s t} & +e_{\mathrm{Fe}-\mathrm{Fe}}^{1 s t}-e_{\mathrm{I}_{\mathrm{a}}-\mathrm{Fe}}^{1 s t}-e_{\mathrm{I}_{\mathrm{b}}-\mathrm{Fe}}^{1 s t} \\
& =\frac{\Omega_{\mathrm{I}_{\mathrm{a}}-\mathrm{I}_{\mathrm{b}}}^{1 s}}{8 N}+\frac{1}{2} E_{\text {int }}^{1 s t}\left(\mathrm{I}_{\mathrm{a}}-\mathrm{I}_{\mathrm{a}}\right)+\frac{1}{2} E_{\text {int }}^{1 s t}\left(\mathrm{I}_{\mathrm{b}}-\mathrm{I}_{\mathrm{b}}\right)
\end{aligned}
$$

Here, $e \mathrm{I}_{\mathrm{a}} \mathrm{I}_{\mathrm{b}}{ }^{1 \mathrm{st}}, e \mathrm{Fe}-\mathrm{Fe}{ }^{1 \mathrm{st}}, e \mathrm{I}_{\mathrm{a}}-\mathrm{Fe}^{1 \mathrm{st}}$, and $e \mathrm{I}_{\mathrm{b}}-\mathrm{Fe}^{1 \mathrm{st}}$ are first neighboring bond energy values of $\mathrm{I}_{\mathrm{a}}-\mathrm{I}_{\mathrm{b}}, \mathrm{Fe}-\mathrm{Fe}, \mathrm{I}_{\mathrm{a}}-\mathrm{Fe}$, and $\mathrm{I}_{\mathrm{b}}-\mathrm{Fe}$, and $N$ is the numbers of atoms. The second neighboring interaction between impurities is also expressed as

$$
\begin{aligned}
E_{\text {int }}^{2 n d}\left(\mathrm{I}_{\mathrm{a}}-\mathrm{I}_{b}\right)= & e_{\mathrm{I}_{\mathrm{a}}-\mathrm{I}_{\mathrm{b}}}^{2 n d}+e_{\mathrm{Fe}-\mathrm{Fe}}^{2 n d}-e_{\mathrm{I}_{\mathrm{a}}-\mathrm{Fe}}^{2 n d}-e_{\mathrm{I}_{\mathrm{b}}-\mathrm{Fe}}^{2 n d} \\
& =\frac{\Omega_{\mathrm{I}_{\mathrm{a}}-\mathrm{I}_{b}}^{2 n}}{3 N}+\frac{1}{2} E_{\text {int }}^{2 n d}\left(\mathrm{I}_{\mathrm{a}}-\mathrm{I}_{\mathrm{a}}\right)+\frac{1}{2} E_{\text {int }}^{2 n d}\left(\mathrm{I}_{\mathrm{b}}-\mathrm{I}_{\mathrm{b}}\right)
\end{aligned}
$$

The interaction parameter between impurities per atom considering the first and second neighboring bond energy is expressed as

$$
\begin{aligned}
\frac{\Omega_{\mathrm{I}_{\mathrm{a}}-\mathrm{I}_{\mathrm{b}}}}{N}= & \frac{\Omega_{\mathrm{I}_{\mathrm{a}}-\mathrm{I}_{\mathrm{b}}}^{1 s s}}{N}+\frac{\Omega_{\mathrm{I}_{\mathrm{a}}-\mathrm{I}_{\mathrm{b}}}^{2 n d}}{N} \\
= & 8 E_{\text {int }}^{1 s t}\left(\mathrm{I}_{\mathrm{a}}-\mathrm{I}_{\mathrm{b}}\right)-4 E_{\text {int }}^{1 s t}\left(\mathrm{I}_{\mathrm{a}}-\mathrm{I}_{\mathrm{a}}\right)-4 E_{\text {int }}^{1 s t}\left(\mathrm{I}_{\mathrm{b}}-\mathrm{I}_{\mathrm{b}}\right) \\
& \quad+3 E_{\text {int }}^{2 n d}\left(\mathrm{I}_{\mathrm{a}}-\mathrm{I}_{\mathrm{b}}\right)-\frac{3}{2} E_{\text {int }}^{2 n d}\left(\mathrm{I}_{\mathrm{a}}-\mathrm{I}_{\mathrm{a}}\right)-\frac{3}{2} E_{\text {int }}^{2 n d}\left(\mathrm{I}_{\mathrm{b}}-\mathrm{I}_{\mathrm{b}}\right)
\end{aligned}
$$

Table 2 shows the interaction parameter between impurities per atom. These indicate that the bonds of $\mathrm{Cu}-\mathrm{Si}$ are more stable than the separately created bonds of $\mathrm{Si}-\mathrm{Si}$ and $\mathrm{Cu}-\mathrm{Cu}$ as described above. It is noted that the bonds of $\mathrm{Si}-\mathrm{Ni}$ are also more stable. On the other hand, the stability of the bonds of $\mathrm{Cu}-\mathrm{Ni}$ is comparable to that of the separately created bonds of $\mathrm{Ni}-\mathrm{Ni}$ and $\mathrm{Cu}-\mathrm{Cu}$. This suggests that the segregation of the solute-atom cluster containing $\mathrm{Si}$ with $\mathrm{Cu}$ and $\mathrm{Ni}$ is likely to be encouraged, but that the interaction between $\mathrm{Cu}$ and $\mathrm{Ni}$ is small.

Table 2 Interaction parameter between impurities

\begin{tabular}{cc}
\hline Impurities & $\begin{array}{c}\text { Interaction parameter } \\
(\mathrm{eV})\end{array}$ \\
\hline $\mathrm{Cu}$ and $\mathrm{Si}$ & -1.57 \\
$\mathrm{Cu}$ and $\mathrm{Ni}$ & 0.07 \\
$\mathrm{Si}$ and $\mathrm{Ni}$ & -1.34 \\
\hline
\end{tabular}


Density of states (arb. units)

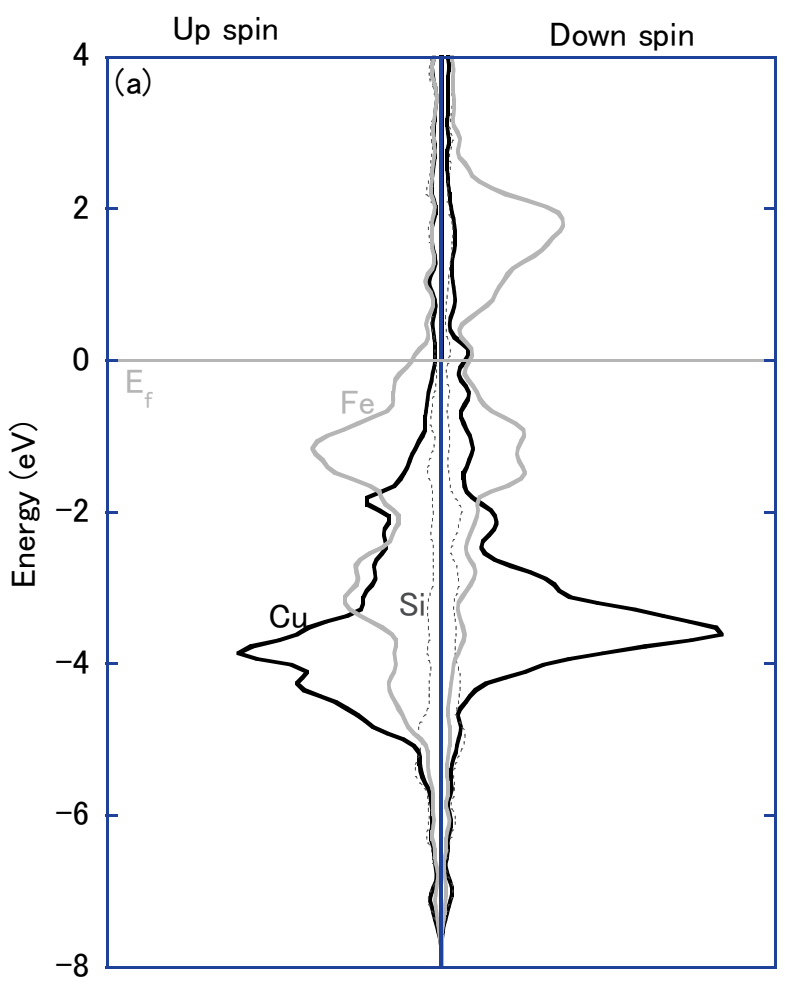

Density of states (arb. units)

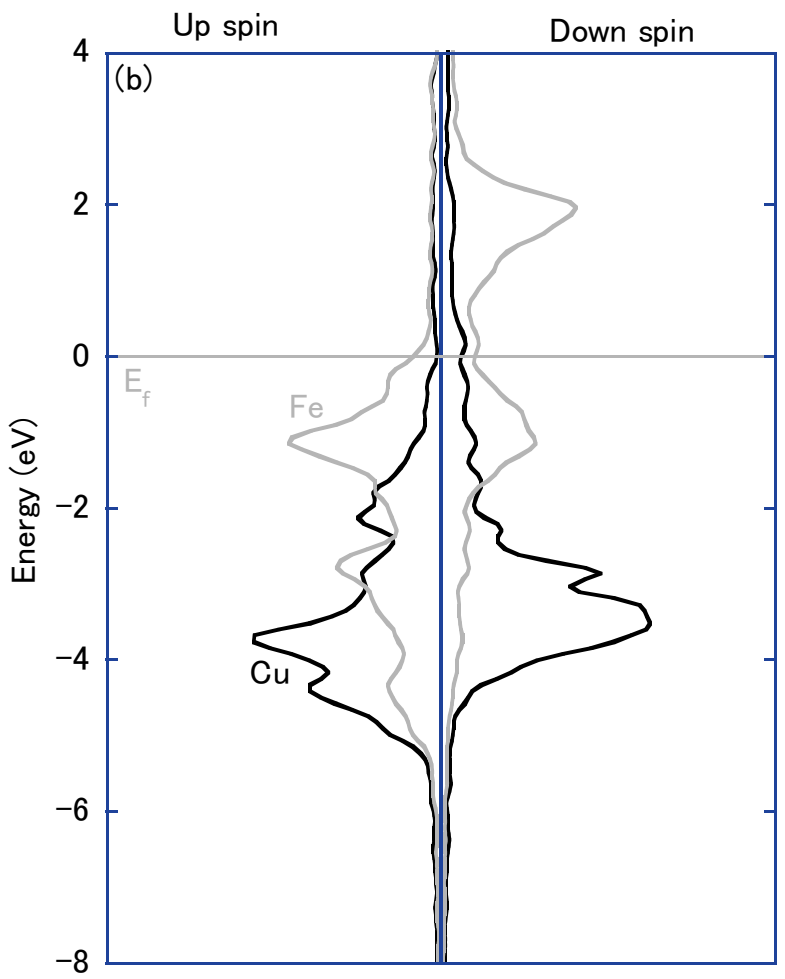

Fig. 1 (a) Density of states (DOS) of $\mathrm{Cu}$ and adjacent $\mathrm{Fe}$ of $\mathrm{Cu}-$ $\mathrm{SiFe}_{14}$ and (b) that of $\mathrm{Cu}_{2} \mathrm{Fe}_{14}$, whose bonds of $\mathrm{Cu}-\mathrm{Si}$ and $\mathrm{Cu}-\mathrm{Cu}$ are first neighboring.
Density of states (arb. units)

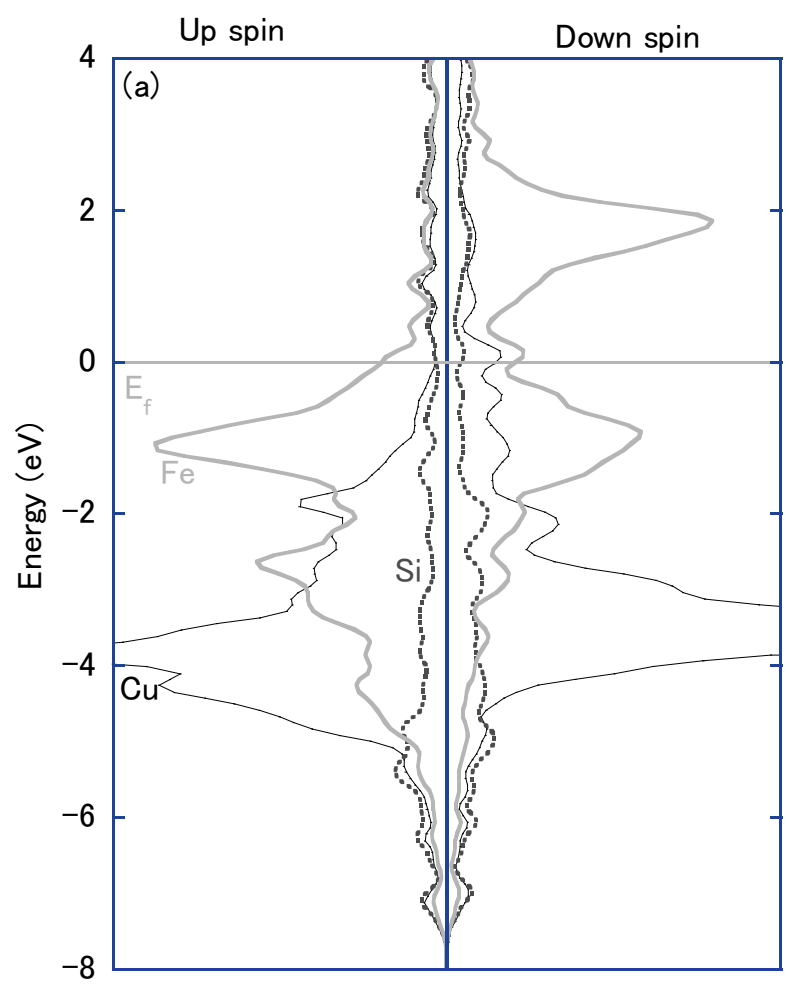

Density of states (arb. units)

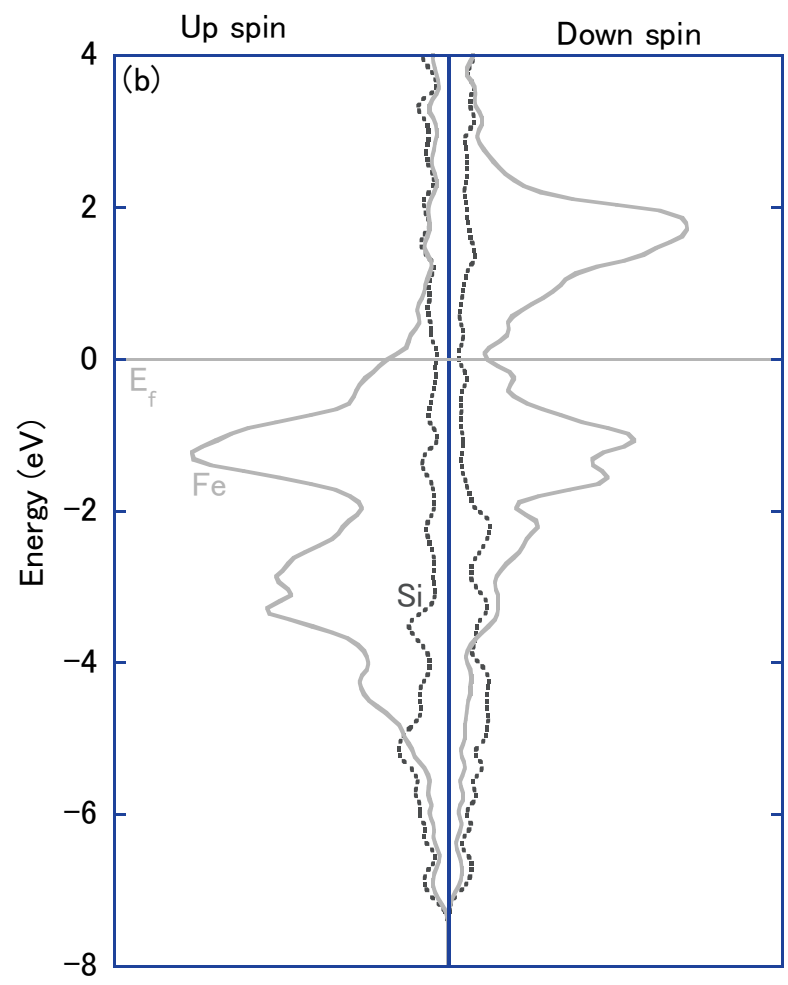

Fig. 2 (a) Density of states (DOS) of $\mathrm{Si}$ and adjacent $\mathrm{Fe}$ of $\mathrm{Cu}-$ $\mathrm{SiFe}_{14}$ and (b) that of $\mathrm{Si}_{2} \mathrm{Fe}_{14}$, whose bonds of $\mathrm{Cu}-\mathrm{Si}$ and $\mathrm{Si}-\mathrm{Si}$ are first neighboring. 


\section{Electronic Structure of $\mathrm{Fe}, \mathrm{Cu}$, and $\mathrm{Si}$}

Tables 1 and 2 show that coexistence of $\mathrm{Cu}$ and $\mathrm{Si}$ is stable. In order to evaluate the effect of the coexistence of $\mathrm{Cu}$ and $\mathrm{Si}$, Figure 1 shows (a) density of states (DOS) of $\mathrm{Cu}$ and adjacent $\mathrm{Fe}$ of $\mathrm{CuSiFe}_{14}$ and (b) that of $\mathrm{Cu}_{2} \mathrm{Fe}_{14}$, whose bonds of $\mathrm{Cu}-\mathrm{Si}$ and $\mathrm{Cu}-\mathrm{Cu}$ are first neighboring.

These figures indicate that up spin DOS of $\mathrm{Cu}$ of $\mathrm{CuSiFe}_{14}$ in the occupied range has a peak at $-3.9 \mathrm{eV}$ and that that of $\mathrm{Cu}_{2} \mathrm{Fe}_{14}$ has a peak at $-3.8 \mathrm{eV}$. It is noted that down spin DOS of $\mathrm{Cu}$ of $\mathrm{CuSiFe}_{14}$ in the occupied range has a peak at $-3.6 \mathrm{eV}$, but that of $\mathrm{Cu}_{2} \mathrm{Fe}_{14}$ has a smaller peaks at $-3.5 \mathrm{eV}$ and $-2.9 \mathrm{eV}$. These electronic structures of $\mathrm{Cu}$ suggest that $\mathrm{Cu}$ component is of lower energy in $\mathrm{CuSiFe}_{14}$ than in $\mathrm{Cu}_{2} \mathrm{Fe}_{14}$. On the other hand, DOS of $\mathrm{Fe}$ adjacent to $\mathrm{Cu}$ of $\mathrm{CuSiFe}_{14}$ is of a little lower energy than that of $\mathrm{Cu}_{2} \mathrm{Fe}_{14}$.

Figure 2 shows (a) density of states (DOS) of Si and adjacent $\mathrm{Fe}$ of $\mathrm{CuSiFe}_{14}$ and (b) that of $\mathrm{Si}_{2} \mathrm{Fe}_{14}$, whose bonds of $\mathrm{Cu}-\mathrm{Si}$ and $\mathrm{Si}-\mathrm{Si}$ are first neighboring. DOS's of Si and adjacent $\mathrm{Fe}$ of $\mathrm{CuSiFe}_{14}$ are similar to those of $\mathrm{Si}_{2} \mathrm{Fe}_{14}$. These electronic structures shown in Figs. 1 and 2 suggest that the coexistence of $\mathrm{Cu}$ and $\mathrm{Si}$ stabilizes $\mathrm{Cu}$ and adjacent $\mathrm{Fe}$ component.

The electronic structures of $\mathrm{Si}, \mathrm{Ni}$, and $\mathrm{Fe}$ adjacent to $\mathrm{Ni}$ of $\mathrm{SiNiFe}_{14}$, whose bond of $\mathrm{Si}-\mathrm{Ni}$ is first neighboring, are different from those of $\mathrm{Si}_{2} \mathrm{Fe}_{14}$ and $\mathrm{Ni}_{2} \mathrm{Fe}_{14}$. These differences are likely to cause the energy stabilization of $\mathrm{SiNiFe}_{14}$.

The electronic structures of $\mathrm{Cu}, \mathrm{Ni}$, and $\mathrm{Fe}$ adjacent to $\mathrm{Ni}$ of $\mathrm{CuNiFe}_{14}$, whose bond of $\mathrm{CuNi}$ is first neighboring, are similar to those of $\mathrm{Cu}_{2} \mathrm{Fe}_{14}$ and $\mathrm{Ni}_{2} \mathrm{Fe}_{14}$. This similarity suggests that the interaction parameter of $\mathrm{Cu}-\mathrm{Ni}$ is small. Consequently, the effect of the coexistence of $\mathrm{Cu}$ and $\mathrm{Ni}$ is small.

\section{Conclusion}

We calculated the electronic state of $\alpha-\mathrm{Fe}$ containing $\mathrm{Cu}$, $\mathrm{Si}$, and $\mathrm{Ni}$ to examine the interaction between these impurities. This calculation indicted that the stability of the interaction between impurities was $\mathrm{Cu}-\mathrm{Cu}>\mathrm{Ni}-\mathrm{Ni}>\mathrm{Si}-\mathrm{Si}$, and that the bonds of $\mathrm{Cu}-\mathrm{Si}$ and $\mathrm{Si}-\mathrm{Ni}$ were more stable than that of $\mathrm{Si}-\mathrm{Si}$. In addition, we estimated the interaction parameter between impurities considering first and second neighboring interaction. This estimation suggested that the interaction parameters of $\mathrm{Cu}-\mathrm{Si}$ and $\mathrm{Si}-\mathrm{Ni}$ were stable and that $\mathrm{Cu}$ and $\mathrm{Ni}$ impurity encouraged segregation of solute-atom clusters containing $\mathrm{Si}$ atoms.

We evaluated the effect of the coexistence of impurities from the view point of the electronic structure. In case of coexistence of $\mathrm{Cu}$ and $\mathrm{Si}$, the energy of $\mathrm{Cu}$ and adjacent $\mathrm{Fe}$ component was lowered. This electronic structure suggested that the coexistence of $\mathrm{Cu}$ and $\mathrm{Si}$ stabilized $\mathrm{Cu}$ and adjacent $\mathrm{Fe}$ component. As for the coexistence of $\mathrm{Si}$ and $\mathrm{Ni}$, the difference of the electronic structures was likely to cause the energy stabilization. On the other hand, the effect of the coexistence of $\mathrm{Cu}$ and $\mathrm{Ni}$ was small.

\section{References}

1) G. R. Odette, "On the dominant mechanism of irradiation embrittlement of reactor pressure vessel steels," Scpripta Metall., 17[10], 1183-1186 (1983).

2) K. L. Murty, "Beneficial(!) effect of neutron irradiation on mechanical properties of mild steel in blue brittle range," Scpripta Metall., 18[1], 87-89 (1984).

3) W. J. Phythiann, A. English, "Microstructural evolution in reactor pressure vessel steels," J. Nucl. Matet., 205, 162-177 (1993).

4) J. T. Buswell, W. J. Phythian, R. J. McEloy, S. Dumbil, P. H. N. Rayand, J. Mace, R. N. Sinclair, "Irradiation-induced microstructural changes, and hardening mechanisms, in model PWR reactor pressure vessel steels," J. Nucl. Mater., 225, 196-214 (1995).

5) Q. Xu, T. Yoshiie, K. Sato, "Dose dependence of $\mathrm{Cu}$ precipitate formation in $\mathrm{Fe}-\mathrm{Cu}$ model alloys irradiated with fission neutrons," Phys. Rev., B73[13], 134115 (2006).

6) T. Toyama, Y. Nagai, Z. Tang, M. Hasegawa, A. Almazouzi, E. van Walle, R. Garard, "Nanostructural evolution in surveillance test specimens of a commercial nuclear reactor pressure vessel studied by three-dimensional atom probe and positron annihilation," Acta Mater., 55[20], 6852-6860 (2007).

7) N. Soneda, K. Doi, A. Nomoto, K. Nishida, S. Ishino, Development of neutron irradiation embrittlement correlation of reactor pressure vessel materials of light water reactor, CRIEPI Research Report Q06019, Central Research Institute of Electronic Power Industry (CRIEPI) (2006), [in Japanese].

8) K. Doi, K. Nishida, A. Nomoto, N. Soneda, H. Watanabe, $3 D$ atom probe obervation of heavy ion irradiated model alloys for reactor pressure vessel steels, CRIEPI Research Report Q08026, Central Research Institute of Electronic Power Industry (CRIEPI) (2009), [in Japanese].

9) K. Doi, K. Nishida, A. Nomoto, T. Hamaoka, N. Soneda, Effect of irradiation temperature on hardening and microstructural changes of heavy ion irradiated reactor pressure vessel model alloys, CRIEPI Research Report Q09026, Central Research Institute of Electronic Power Industry (CRIEPI) (2010), [in Japanese].

10) T. Tsuru, C. Suzuki, Y. Kaji, T. Tsukada, "Non-empirical prediction of impurity segregation in alpha-Fe from first principles," J. Appl., Phys., 107[6], 061805 (2010).

11) T. Ohmura, N. Soneda, M. Iwasawa, "First-principles calculations of vacancy-solute element interactions in body centered cubic iron," Acta Mater., 57[20], 5947-5955 (2009).

12) The "PHASE" code was created by the members of the national project "Frontier Simulation Software for Industrial Science (FSIS)". PHASE ver. 7.01 is downloaded from RSS21 (http://www.ciss.iis.u-tokyo.ac.jp/rss21/index.html).

13) J. P. Perdew, K. Burke, M. Emzerhof, "Generalized Gradient Approximation Made Simple," Phys. Rev. Lett., 77[18], 38653968 (1996).

14) D. Vanderbilt, "Soft self-consistent pseudopotentials in a generalized eigenvalue formalism," Phys. Rev., B41[11], 78927895 (1990).

15) K. Laasonen, A. Pasquqrello, R. Car, C. Lee, D. Vanderbilt, "Car-Parrinello molecular dynamics with Vanderbilt ultrasoft pseudopotentials," Phys. Rev., B47[16], 10142-10153 (1993).

16) Y. Iwasawa (Ed.), Kagaku Binran Kisohen vol. 2, 5th ed., Maruzen, Tokyo, 846-847 (2003). 